\title{
RELEVANSI PEMIKIRAN EKONOMI YAHYA BIN UMAR DALAM PERSPEKTIF EKONOMI MODERN
}

\author{
Moh. Subhan \\ STAI Miftahul Ulum Pamekasan \\ e-mail: orsatpmk@gmail.com
}

\begin{abstract}
Islam as a religion has rules about life and the life of mankind in plenary, although sometimes it is only globally. The dimension of relationship between humans and god is static, while the dimension of relationship between human and social environment is dynamic and flexible. The second dimension of man is given the broader freedom to make rules and regulations according with the circumstance and condition of times by sticking to the rules of Sharia. This article will try to elaborate the economic thought of Yahya ibn Umar in his book Ahsat al-Sux, which is of relevance to the conventional economics. The objective of research is to know whether the brilliant idea of Yahya ibn Umar in his time (Century III H) is still relevant to be applied to the modern era or not. Broadly speaking, Yahya bin Umar's thought on hssbah and matters related to markets

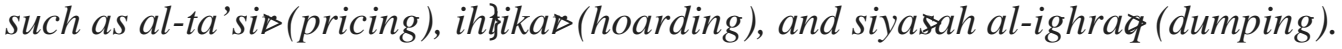

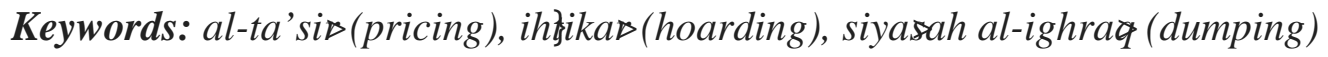

\section{Pendahuluan}

Yahya ibn Umar merupakan salah satu ulama abad 9 M dari Mazhab Maliki yang sangat produktif dalam menuangkan ide-idenya menjadi karya tulis yang bermanfaat bagi orang banyak. Nama lengkapnya adalah Abu Bakar Yahya ibn Umar ibn Yusuf al-Kannani alAndalusi. Dilahirkan pada tahun 213 H/930 M dan dibesarkan di Cordova, Spanyol. Sebagaimana para tokoh muslim lainnya, ia juga melakukan rihbah ilmiah ke berbagai negeri untuk menuntut ilmu.

Rihlah ilmiah pertama ia lakukan ke Mesir dan berguru kepada sahabat Abdullah bin Wahab al-Maliki dan Ibn al-Qasim, seperti Ibnu al-Kirwan Ramh dan Abu al-Zhahir bin alSarh. Rihlah ilmiah berikutnya ke Hijaz dan berguru kepada Abu Mus'ab al-Zuhri. Yahya ibn Umar menetap di Qairuwan ${ }^{1}$ dan menyempurnakan pendidikannya kepada seorang ahli Ilmu Faraid dan Hisab, Abu Zakaria Yahya bin Sulaiman al-Farisi. ${ }^{2}$

Disamping mengajar, ia juga banyak menghasilkan karya tulis hingga mencapai kurang lebih dari 40 juz, di antaranya kitab al-Muntakhabah fi ¥khtisa $\gg$ al-Mustakhrijah fi $x l$-Fiqh alMatiki dan kitab Ahłam al-Suæ. Kitab Ahłam al-Suæ ini merupakan kitab pertama di dunia Islam yang khusus membahas $h$ şbah dan berbagai hukum pasar.

\footnotetext{
${ }^{1}$ Qairuwan adalah sebuah kota yang terletak di bagian utara Tunisia dan ibukota dari Provinsi Kairouan. Kota ini terletak di selatan Sousse, 50 kilometer dari pantai timur atau 184 kilometer dari kota Tunis. Kota ini dibangun oleh orang Arab sekitar tahun 670 Masehi.Pada periode Dinasti Umayah, kota ini menjadi pusat pendidikan Islam dan pembelajaran al-Quran sehingga menarik sejumlah besar muslim dari berbagai belahan dunia. Kota Kairouan sekarang merupakan bagian dari warisan dunia Islam, pada tahun 2009 ditetapkan sebagai ibukota budaya dunia Islam.

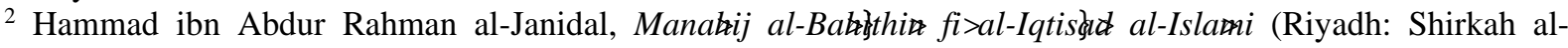
Ubaikan li al-Tłbaða wa al-Nashr, 1406 H), 118.
} 
Kitab Ahłam al-Suф terasa lebih membumi karena kitab tersebut merupakan hasil dialektika Yahya ibn Umar dengan lingkungan sosialnya, yaitu kota Qairuwan yang terletak di Afrika Utara. Sebuah kota yang sudah memiliki institusi pasar yang permanen sejak tahun 772 M. Di samping itu, kota ini juga telah memiliki lembaga peradilan dengan seorang hakim khusus yang menangani berbagai permasalahan pasar.

Sekalipun tema utama dalam kitab tersebut mengkaji mengenai persoalan dan problem yang berkaitan dengan pasar, tetapi pada dasarnya Umar ibn Yahya lebih banyak membahas tentang persoalan ihtika dan siyasah al-ighraæ. Kedua istilah tersebut dalam ilmu ekonomi kontemporer dikenal dengan monopoly's rent-seeking (ihtika $\gg$ ) dan dumping policy (siyasah al-ighra $\ngtr){ }^{3}$

Agar pembahasan dalam tulisan ini lebih terfokus, maka penulis akan membagi dalam tiga pokok bahasan. Pertama, pemikiran Yahya ibn Umar tentang ihłika (monopoly's rentseeking). Kedua, pemikiran Yahya ibn Umar tentang siyasah al-ighrał (dumping policy) dan kebijakan pemerintah. Ketiga, pemikiran Yahya ibn Umar tentang pasar, dalam hal ini ta'si» (penetapan harga) kaitannya dengan peran pemerintah.

Kajian dalam tulisan ini akan terasa lebih menarik dan berkualitas, sebab dalam pembahasannya tidak hanya memperbincangkan gagasan Yahya ibn Umar, tetapi gagasan tersebut akan dikorelasikan dengan pemikiran ekonomi modern. Dari paparan tersebut akan diketahui dan dipahami, apakah ide yang diusung oleh Yahya ibn Umar pada 15 abad yang silam masih relevan dengan pemikiran para ekonom abad modern. Jika hal tersebut dapat dibuktikan, maka akan menambah optimisme bagi umat Islam untuk melaksanakan dan mengembangkan ekonomi Islam tersebut.

\section{Pemikiran Yahya ibn Umar tentang Iht\}ka®(Monopolys Rent-Seeking).}

Monopoli atau ihtika $\gg$ adalah menimbun barang agar yang beredar di masyarakat berkurang, lalu harganya naik. Islam secara tegas melarang praktek ihtika ${ }^{4}{ }^{4}$ sebab ihtika dapat mengakibatkan terganggunya mekanisme pasar, dimana penjual akan menjual sedikit barang dagangannya, sementara permintaan terhadap barang tersebut sangat banyak, sehingga di pasar terjadi kelangkaan barang. Berdasarkan hukum ekonomi, maka semakin sedikit persediaan barang di pasar, maka harga barang semakin naik dan permintaan terhadap barang semakin berkurang.

Dalam kondisi seperti ini produsen dapat menjual barangnya dengan harga yang lebih tinggi dari harga normal. Penjual akan mendapatkan keuntungan yang lebih besar dari keuntungan normal (super normal profit), sementara konsumen akan menderita kerugian. Jadi, akibat ihlika masyarakat akan dirugikan oleh ulah sekelompok kecil manusia. Oleh karena itu, dalam pasar monopoli seorang produsen dapat bertindak sebagai price maker (penentu harga).

Para ulama sepakat bahwa 'illat pengharaman ihłika»adalah karena dapat menimbulkan kemudaratan bagi manusia. ${ }^{5}$ Sedangkan kemudaratan merupakan sesuatu yang harus

\footnotetext{
${ }^{3}$ Nur Hamid, Jejak Langkah Sejarah Pemikiran Ekonomi Islam (Yogyakarta: Pustaka Pelajar, 2010), 203.

${ }^{4}$ Ihtik $\gg$ adalah perbuatan menimbun atau menahan (holding) barang dengan maksud untuk menaikkan harga di kemudian hari untuk memperoleh keuntungan yang berlimpah (monopolistic rent).

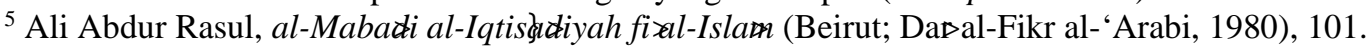


dihilangkan. Implikasi lebih jauh, ihłika tidak hanya akan merusak mekanisme pasar, tetapi juga akan menghentikan keuntungan yang akan diperoleh orang lain dan dapat menghambat proses distribusi kekayaan di antara manusia, ${ }^{6}$ sebab konsumen masih harus membayar harga produk yang lebih tinggi dari ongkos marjinal. Oleh karena itu, praktek ihtika» akan menghambat kesejahteraan umat manusia. Padahal salah satu tujuan dari sistem ekonomi, apapun bentuknya adalah kesejahteraan umat manusia.

Menurut Yahya ibn Umar, apabila harga di pasar mengalami ketidakstabilan karena ulah oknum pedagang, maka pemerintah sebagai lembaga formal boleh melakukan intervensi terhadap harga di pasar tersebut, dengan mengembalikan tingkat harga pada equilibrium price (keseimbangan harga).

Tindakan yang bisa dilakukan oleh pemerintah dalam mengatasi kasus ihlika adalah akan menjual barang dagangan hasil timbunan sesuai dengan harga pasar pada saat itu. Jika dalam penjualan barang tersebut terdapat keuntungan, maka keuntungan tersebut akan disedekahkan kepada fakir miskin. Sedangkan pelaku ihtika hanya berhak mendapatkan modal pokonya saja.

Jadi, tindakan yang dilakukan oleh pemerintah dalam kasus tersebut bertujuan untuk memberikan pembelajaran terhadap pelaku ihtika . Selanjutnya, pemerintah akan memberikan teguran kepada pelaku ihtika agar tidak mengulangi perbuatannya lagi. Apabila pelaku ihlika $\gg$ tidak memperhatikan teguran tersebut, pemerintah berhak menghukum mereka dengan memukulnya, lari mengelilingi kota dan memenjarakannya.

Tetapi yang harus dipahami lebih lanjut adalah, sesuatu baru dikatakan sebagai ihtika〉 jika pertama, barang yang ditimbun merupakan kebutuhan pokok (basic need) masyarakat. Kedua, penimbunan dilakukan dengan tujuan untuk memperoleh keuntungan di atas keuntungan normal (super normal profit). Dan ketiga, barang yang ditimbun adalah melebihi dari kebutuhannya, berikut tanggungan untuk persediaan setahun penuh. ${ }^{7}$ Tindakan seseorang yang menyimpan stok barang tertentu untuk kepentingan persediaan, seperti ketika terjadi panen raya atau untuk persediaan kebutuhan pribadinya tidak bisa dikatakan sebagai tindakan ihtika . Sebab hal tersebut tidak akan mengakibatkan kelangkaan barang di masyarakat, justru jika hal itu tidak dilakukan oleh perusahaan atau produsen tertentu harga barang akan anjlok dan rakyat akan mengalami kerugian. ${ }^{8}$

Sementara itu, pemerintah Indonesia melalui Peraturan Pemerintah Nomor 20 Tahun 1948 tentang Penimbunan Kebutuhan Bahan Pokok, seperti beras, gabah, padi, menir, tepung beras, gula dalam jumlah tertentu. Beras, gabah, padi, menir, tepung beras, dan gula, masingmasing tidak boleh lebih dari 500 kilogram. ${ }^{9}$ Berdasarkan undang-undang tersebut, berarti pemerintah memperbolehkan melakukan penimbunan barang oleh institusi tertentu dengan maksud untuk melindungi konsumen dan produsen. Sedangkan penimbunan yang dimaksudkan untuk mendapatkan keuntungan maksimal dan merugikan pihak lain adalah dilarang.

Modus yang dilakukan oleh perusahaan atau produsen dalam melakukan tindakan

\footnotetext{
${ }^{6}$ M. Yusuf, Economic Justice in Islam (New Delhi: Kitab Bavhan, 1988), 42.

${ }^{7}$ Sayyid Sabiq, Fiqh al-Sunnah (Libanon: Daæal-Fikr, 1981), 100. Lihat juga Adiwarman Azwar Karim, Sejarah Pemikiran Ekonomi Islam (Jakarta: PT. Raja Grafindo Persada, 2014), 299.

${ }^{8}$ P3EI UII dan BI, Ekonomi Islam (Yogyakarta: PT. Raja Grafindo Persada, 2008), 333.

${ }^{9}$ PP No. 20/1948 Tentang Penimbunan Barang Penting Pasal 1 ayat 1.
} 
ihtika bermacam-macam, di antaranya:

1. Volume produksi (kuantitas barang) lebih kecil dari volume output yang optimum (Qm), padahal produsen sebenarnya mampu untuk memproduksi dalam jumlah yang lebih besar (Q) atau paling tidak di titik (Q1).

2. Ada kemungkinan keuntungan monopoli tetap bisa dinikmati produsen monopoli dalam jumlah yang besar dan jangka panjang (PmXYZ).

3. Ada unsur "eksploitasi" oleh perusahaan-perusahaan monopoli terhadap:

a. Konsumen, dengan ditetapkan harga jual (=P) di atas ongkos produksi dari unit terakhir outputnya (=MC).

b. Pemilik faktor-faktor produksi yang digunakan oleh produsen monopoli tersebut, dengan dibayarnya faktor produksi dengan harga $(=\mathrm{MC})$ yang lebih rendah dari nilai pasar dari output yang dihasilkan (=P).

c. Kualitas barang lebih rendah, dan konsumen terpaksa membeli, sebab tidak ada barang lainnya.

Sebagai ilustrasi dapat dilihat pada gambar berikut:

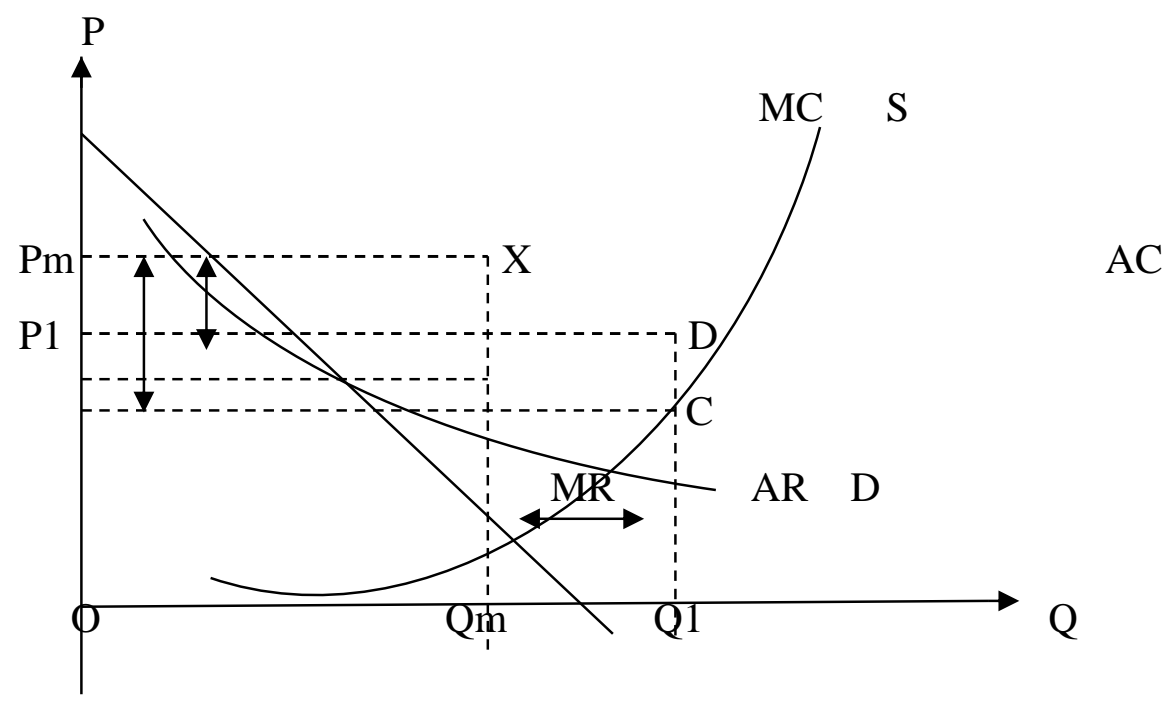

Dari paparan di atas, jelas bahwa antara pemikiran Yahya ibn Umar yang digagasnya sekitar 15 abad yang lalu terdapat kesesuaian dengan ekonomi modern yang juga melarang adanya praktek monopoli murni (pure monopoly) dan adanya sanksi bagi pihak yang melanggarnya. Meskipun bahasa yang digunakan oleh Yahya ibn Umar sangat sederhana.

Monopoli murni adalah suatu keadaan dimana dalam pasar hanya ada satu penjual, sehingga tidak ada pihak lain yang menyainginya. Di negara yang terkenal dengan pasar bebas dan sistem kapitalisnya, seperti Amerika Serikat masih terdapat Undang-Undang Anti Trust. Bahkan pemerintah Indonesia menerbitkan Undang-Undang Nomor 5 Tahun 1999 tentang Larangan Praktek Monopoli dan Persaingan Tidak Sehat.

Pada dasarnya peraturan tentang persaingan usaha yang sehat cukup banyak ragamnya, masing-masing dikeluarkan melalui undang-undang tersendiri di berbagai negara maju di dunia. Penelusuran dari informasi yang ada, umumnya negara-negara tersebut mengeluarkan peraturan permainan persaingan usaha yang sehat, dengan melarang hal-hal berikut ini:

1. Larangan melakukan persengkongkolan bisnis yang merugikan pesaing lainnya.

2. Monopoli atau memperoleh hak khusus atas dasar KKN dengan birokrat. 
3. Proses tender yang tidak transparan, atau menggunakan perusahaan alibaba.

4. Differensiasi harga pada kelompok bisnis tertentu yang merugikan pihak pesaing.

5. Proses merger dan akuisisi yang ditujukan untuk mengurangi tingkat persaingan.

6. Horizontal dan vertical merger yang mengarah pada dominasi konsentrasi pasar. (vertical merger untuk tujuan efisiensi dan pengurangan harga jual masih diperbolehkan).

7. Proses produksi, kualitas produk, dan kampanye iklan yang merugikan pihak konsumen.

8. Memberikan informasi tentang produk dan pelayanan yang menyesatkan kepentingan konsumen.

Dalam Pasal 17 ayat 1 Undang-Undang Nomor 5 Tahun 1999 dinyatakan bahwa pelaku usaha dilarang melakukan penguasaan atas produksi dan atau pemasaran barang dan atau jasa yang dapat mengakibatkan terjadinya praktek monopoli dan atau persaingan usaha tidak sehat.

Pasal 47 dan 48 Undang-Undang Nomor 5 Tahun 1999 disebutkan apabila terjadi pelanggaran terhadap undang-undang tersebut maka pemerintah dapat mengenakan sanksi bagi pelakunya, baik sanksi administrasi (penggagalan perjanjian atau denda serendahrendahnya Rp. 1.000.000.000,- dan setinggi-tingginya Rp. 25.000.000.000,- atau Rp. 1.000.000.000,- dan sanksi berupa kurungan minimal 3 bulan sampai 6 bulan.

\section{Pemikiran Ekonomi Yahya ibn Umar tentang Siyasah al-Ighraథ(Dumping Policy)}

Siyasah al-ighraæ (dumping) adalah sebuah aktivitas perdagangan yang bertujuan untuk mencari keuntungan dengan jalan menjual barang pada tingkat harga yang lebih rendah dari harga yang berlaku di pasaran. Perilaku seperti ini secara tegas dilarang oleh agama karena dapat menimbulkan kemudlaratan bagi masyarakat.

Siyasah al-ighra (dumping) dilakukan oleh seseorang dengan maksud agar para pesaing dagangnya mengalami kebangkrutan. Dengan demikian, ia akan leluasa menentukan harga di pasar. Siyasah al-ighra atau banting harga (dumping) dapat menimbulkan persaingan yang tidak sehat serta dapat mengacaukan stabilitas harga di pasar. Dalam kondisi seperti ini pemerintah mempunyai otoritas untuk memerintahkan para pedagang tersebut agar menaikkan kembali harga barang sesuai dengan harga yang berlaku di pasar. Apabila mereka tidak mau mentaati aturan pemerintah, maka pemerintah berhak mengusir para pedagang tersebut dari pasar. Hal ini pernah dipraktekkan oleh Khalifah Umar ibn al-Khaththab, ketika mendapati seorang pedangang kismis yang menjual barang dagangannya di bawah standar harga di pasar. Maka Khalifah Umar ibn al-Khaththab memberikan pilihan kepada pedagang tersebut, yaitu menaikkan harga sesuai dengan harga standar di pasar atau keluar dari pasar.

Dalam sistem negara modern dewasa ini, keterlibatan negara dalam mengontrol pasar khususnya yang terkait dengan fluktuasi harga barang dan regulasi pasar semakin dibutuhkan. Kebutuhan akan peran pemerintah semakin diperlukan sebagai akibat dari meningkatnya pola-pola ketidakadilan para pelaku pasar bebas yang berujung pada merebaknya otoritasi kontrol harga yang terpusat pada segelintir orang. Di samping mentalitas para spekulan yang hanya berorientasi mengeruk keuntungan sepihak dengan mengorbankan kepentingan rakyat. Seperti penimbunan barang-barang kebutuhan pokok khususnya pada saat permintaan barang meningkat di hari-hari besar umat Islam atau tahun baru dan lain-lain. Tidak mengherankan jika pada hari-hari besar tersebut tiba-tiba harga barang meningkat tajam, atau stok habis dari 
peredaran. Bahkan kelangkaan juga tejadi pada barang yang jelas-jelas telah mendapatkan subsidi dari pemerintah, seperti gas elpiji dalam ukuran $3 \mathrm{~kg}$ atau minimnya minyak tanah baru-baru ini dan langkanya pupuk di beberapa daerah di Indonesia.

Peran pemerintah untuk menertibkan sekaligus memberikan kenyamanan dalam bentuk memberikan efek jera kepada para pelaku ketidakadilan di atas sungguh diharapkan. Pernah suatu waktu, harga-harga barang di pasar Madinah meningkat tajam, dan hal ini dikeluhkan oleh para sahabat kepada Nabi, dan mereka meminta kepada Nabi untuk mematok harga atas barang-barang di pasar (al-ta'si»). Namun Nabi menolak dengan alasan khawatir hal itu akan merugikan para penjual dari kalangan pemilik barang. Tentu kejadian ini harus dilihat dari konteks waktu diucapkannya perkataan Nabi tersebut, jika seandainya Nabi masih hidup saat ini, niscaya beliau akan setuju dengan permintaan para sahabat untuk memberikan harga standar atas barang-barang yang beredar di pasar. Perubahan karakter pada pelaku bisnis dahulu dan sekarang tentunya yang merubah fatwa tersebut, dan bukan seperti yang disangka oleh para pendukung sistem kapitalis, bahwa hakekatnya Nabi mendukung pasar bebas atau sangat membela kepentingan para pemiliki modal (the capital).

Demikianlah etika pasar dalam Islam, yang tidak semata diarahkan bagi para pelaku bisnis baik pedagang dan pembeli saja, melainkan juga bagi stakeholders atau pada pembenahan sistem secara menyeluruh. Lebih jelasnya, etika pasar dalam Islam ini menghendaki pembenahan sistem dan kerjasama sinergis antara semua unsur baik pelaku bisnis, masyarakat dan pemerintah

\section{Pemikiran Ekonomi Yahya ibn Umar tentang Intervensi Pemerintah terhadap Ta'si (Regulasi Harga)}

Pasar merupakan pusat terjadinya penyediaan (supply) dan permintaan (demand) barang. Kedudukan pasar dalam Islam begitu tinggi, sebab selain bidang pertanian dan perdagangan merupakan salah satu profesi yang sangat dianjurkan oleh Islam. Karakteristik pasar Islam ialah di dalamnya terdapat aturan, mekanisme dan nilai-nilai Islam yang dijadikan standar aktifitas. Karakteristik inilah yang menjadi kekhasan Islam yang tidak mengenal dikotomi ranah dunia dan akhirat. Aktifitas bisnis yang berorientasi materil selalu diimbangi dengan kecintaan membelanjakan harta di jalan Allah (spiritual). Islam merupakan agama yang menjunjung tinggi kebebasan dalam berekonomi. Sehingga Islam memberikan kebebasan kepada umatnya untuk melakukan inovasi dan kreativitas dalam bermuamalah.

Kebebasan ekonomi tersebut juga berarti bahwa harga ditentukan oleh kekuatan pasar, yakni kekuatan penawaran (supply) dan permintaan (demand). Dalam kondisi seperti ini, maka pemerintah dilarang melakukan intervensi terhadap harga. Pada pasal 5 ayat 1 dan 2 Undang-Undang Nomor 5 Tahun 1999 mengindikasikan adanya larangan untuk melakukan persekongkolan dalam rangka menetapkan harga di pasar. Berbicara tentang regulasi harga, tentu kita ingat bahwa pengawasan harga $(h \xi s b a h)^{10}$ muncul pertama kali pada zaman

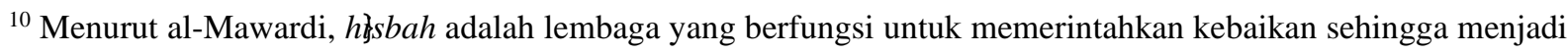
kebiasaan dan melarang hal yang buruk, baik di bidang moral, agama, ekonomi dan secara umum terkait dengan kegiatan kolektif atau publik untuk mencapai keadilan dan kebenaran. $H\{\{s b a h$ disinyalir sudah ada sejak masa Rasulullah. Fugsi $h h_{s} b a h$ antara lain menjaga moral Islam dan perilaku masyarakat muslim, bertanggung jawab atas ketertiban, kenyamanan lalu lintas dan masalah-masalah kerawanan sosial, membawa para pelanggar hukum ke pengadilan.
} 
Rasulullah SAW. Pada masa itu, Rasulullah bertindak sebagai $h \grave{l}$ sib (pengawas) yang dalam versi Indonesia adalah KPPU (Komisi Pengawas Persaingan Usaha). ${ }^{11}$ Kondisi saat itu, masyarakat dihadapkan dalam kondisi harga yang melambung tinggi, sehingga sahabat meminta Rasulullah SAW untuk menurunkan harga. Namun demikian, Rasulullah SAW menolak permintaan sahabat tersebut. Rasulullah mengatakan bahwa Allah mengakui adanya kelebihan dan kekurangan. Dia-lah pembuat harga berubah dan menjadi harga sebenarnya, saya berdoa agar Allah tidak membiarkan ketidakadilan seseorang dalam darah atau hak milik. $^{12}$

Dalam sebuah hadits dinyatakan:

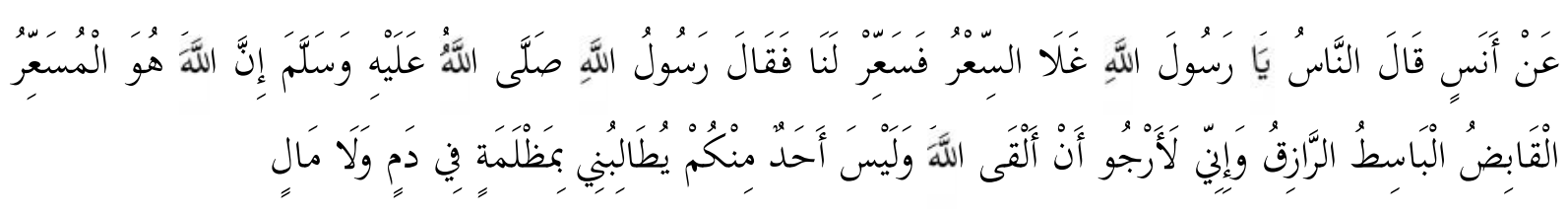

"Dari Anas, ia berkata: Orang-orang berkata, wahai Rasulullah, harga telah naik, maka tetapkanlah harga untuk kami. Lalu Rasulullah SAW bersabda, sesungguhnya Allah yang menetapkan harga, yang mempersempit, dan yang memperluas, dan aku berharap bertemu dengan Allah sedangkan salah salah seorang dari kalian tidak menuntutku karena kezhaliman dalam darah atau harta".

Dari riwayat tersebut, dapat dipahami bahwa penetapan harga secara eksplisit tidak diperkenankan oleh Rasulullah SAW. Sebab dengan penetapan harga akan memicu ketidakadilan baru. Jika harga ditetapkan jauh lebih tinggi maka konsumen akan dirugikan, sebaliknya jika harga ditetapkan sangat rendah, maka produsen yang akan dirugikan. Bagi penulis, hadits di atas dilatarbelakangi oleh kondisi harga yang dalam perspektif Rasulullah SAW masih bisa dijangkau oleh masyarakat. Selain itu, penetapan harga adalah sesuatu yang sensitif, sebab jika terjadi kesalahan dalam menetapkan harga maka akan melahirkan ketidakadilan (injustice) baru dalam kehidupan masyarakat.

Pertanyaan yang muncul kemudian adalah bagaimana jika harga komoditas tidak bisa terjangkau oleh daya beli masyarakat. Dalam hal ini, jika kenaikan harga di pasar diakibatkan oleh ulah para spekulan, sehingga menyebabkan instabilitas (ketidakstabilan) harga di pasar, pemerintah sebagai institusi formal yang mempunyai tanggung jawab menciptakan kesejahteraan umum, berhak melakukan intervensi harga ketika terjadi suatu aktivitas yang dapat membahayakan bagi kehidupan masyarakat luas dengan melakukan stabilisasi. ${ }^{14}$

Dua hal yang membolehkan pemerintah melakukan intervensi terhadap regulasi harga di pasar, yaitu:

1. Para pedagang tidak menjual barang dagangan tertentu (ihłikaðmonopoly’s rent-seeking), padahal masyarakat sangat membutuhkannya, akibat ulah dari sebagian pedagang tersebut, harga di pasar menjadi tidak stabil dan hal tersebut dapat membahayakan

\footnotetext{
11 Kepres No. 75 Tahun 1999 Tentang KPPU.

${ }^{12}$ Hammad ibn Abdur Rahman al-Janidal, Manałij al-Batelthił, 122.

${ }^{13}$ Abu Dawud al-Sijistani, Sunan Abiða円ud, Jilid 4 (Beirut: Daæal-Fikr, 1994), 272.

${ }^{14}$ Kebijakan stabilisasi harga adalah sebagai upaya untuk mengembalikan harga pada kondisi normal. Dengan kata lain, kebijakan penetapan harga hanya diperkenankan dalam kondisi yang amat mendesak, seperti ketika rendahnya daya beli masyarakat. Dalam konteks kekinian, stabilisasi harga dilakukan melalui operasi pasar dan pemberian subsidi pada sektor pangan.
} 
kehidupan masyarakat luas dan mencegah terciptanya masyarakat yang sejahtera. Dalam kondisi seperti itu pemerintah dapat melakukan intervensi agar harga barang menjadi normal kembali.

2. Sebagian pedagang melakukan praktek siyasah al-ighra atau banting harga (dumping). Praktek banting harga dapat menimbulkan persaingan yang tidak sehat serta dapat mengacaukan stabilitas harga di pasar. Dalam kondisi seperti ini pemerintah mempunyai otoritas untuk memerintahkan para pedagang tersebut agar menaikkan kembali harga barang sesuai dengan harga yang berlaku di pasar. ${ }^{15}$

Statemen Yahya ibn Umar tersebut mengindikasikan bahwa ia termasuk salah seorang ulama yang mendukung liberalisasi ekonomi (kebebasan ekonomi), termasuk kebebasan kepemilikan. Sikap Rasulullah SAW yang menolak melakukan penetapan harga melalaui statemennya yang tertuang dalam sebuah hadits riwayat Abu Dawud melalui sanad Anas ibn Malik, juga merupakan indikasi awal bahwa ekonomi Islam tidak hanya mengatur tentang kepemilikan pribadi, tetapi juga menghormati dan melindunginya. Tentu saja, kebebasan ekonomi yang dimaksud bukanlah kebebasan mutlak tanpa batas sebagaimana dalam ekonomi konvensional. Kebebasan yang dimaksud di sini adalah suatu kebebasan yang tetap berada dalam koridor syariat Islam. Kebebasan ekonomi tersebut juga berarti bahwa harga ditentukan oleh kekuatan pasar, yakni kekuatan penawaran (supply) dan permintaan (demand). Sebagaimana teori permintaan dan penawaran.

Dalam hukum permintaan (demand) dinyatakan bahwa jika harga turun, maka permintaan akan naik, dan sebaliknya jika harga naik maka permintaan akan turun. Hukum ini, secara eksplisit menyatakan adanya hubungan negatif antara permintaan dengan harga. Sedangkan dalam hukum penawaran (supply) justru menyatakan adanya hubungan yang positif antara jumlah barang yang ditawarkan dengan harga yang dikenakan.

Jumlah permintaan dan tingkat harga memiliki sifat hubungan yang erat sebagaimana tersebut dalam statemen di atas. Hal ini disebabkan oleh dua hal, yaitu pertama, kenaikan harga menyebabkan para pembeli mencari barang lain yang dapat digunakan sebagai pengganti (substitusi) dari barang yang mengalami kenaikan harga tersebut. Sebaliknya, jika harga turun maka orang mengurangi pembelian terhadap barang lain yang sama jenisnya dan menambah pembelian terhadap barang yang mengalami penurunan harga. Kedua, kenaikan harga menyebabkan pendapatan riil para pembeli berkurang. Hal ini memaksa para pembeli untuk mengurangi pembeliannya terhadap berbagai jenis barang, terutama barang yang mengalami kenaikan. ${ }^{16}$ Tetapi, sekali lagi bahwa mekanisme harga harus tunduk kepada kaidah-kaidah Islam. Di antara kaidah-kaidah tersebut adalah pemerintah berhak melakukan intervensi ketika terjadi tindakan kesewenang-wenangan dalam pasar, seperti ihtika dan siyasah al-ighra atau banting harga (dumping) yang dilakukan oleh oknum tertentu, sehingga menimbulkan kemudlaratan bagi masyarakat secara umum. Hal ini sesuai dengan tugas yang diemban pemerintah dalam upaya mewujudkan keadilan sosial di setiap kehidupan masyarakat, termasuk ekonomi. Sesuai dengan kaidah fikih: ${ }^{17}$

\footnotetext{
${ }^{15}$ Hammad ibn Abdur Rahman al-Janidal, Manałij al-Bablthiæx, 122.

${ }^{16}$ Sudono Sukirno, Mikro Ekonomi Teori Pengantar (Jakarta: Raja Grafindo Persada, 2006), 76.

17 Jalaluddin Abdur Rahman as-Suyuthi, al-Ashba wa al-Naz (Indonesia: Shirkah Nur Asia, tt), 83.
} 


\section{تصرف الامام على الراعية منوط با لمصلحة}

“Tindakan pemimpin terhadap rakyat harus dikaitkan dengan kemaslahatan".

Pernyataan Yahya ibn Umar yang melarang praktek banting harga (dumping) bukan dimaksudkan untuk mencegah harga barang menjadi murah. Tetapi, lebih pada suatu upaya untuk mencegah terjadinya dampak negatif terhadap mekanisme pasar dan kehidupan masyarakat secara keseluruhan. ${ }^{18}$ Jika harga di pasar turun atau murah karena faktor alami tidaklah menjadi masalah, semisal barang di pasar banyak, maka menurut hukum ekonomi harga barang akan turun. Tetapi jika harga di pasar murah, karena ada rekayasa untuk menguasai harga secara monopoli dan berakibat kepailitan pedagang lain, maka hal tersebut dilarang oleh Islam.

\section{Daftar Rujukan}

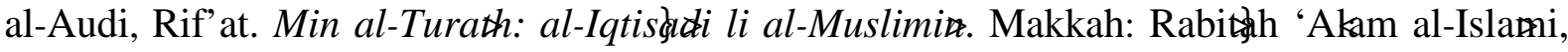
1985.

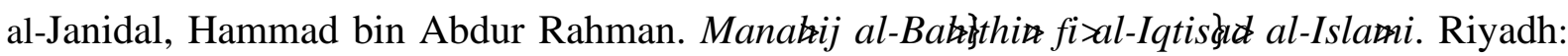
Shirkah al-Ubaikan li al-Tłbałh wa al-Nashr, 1406 H.

al-Sijistani, Abu Dawud. Sunan Abiわa円ud. Beirut: Daæal-Fikr, 1994.

al-Suyuthi, Jalaluddin Abdur Rahman. al-Ashbat wa al-Nazdir. Indonesia: Shirkah Nur Asia, tt.

Antonio, Muhammad Syafii. "Islamic Bank in Indonesia", Thesis of Doctor of Philosophy degree--The University of Melbourne, Australia, 2003.

Chapra, Umer. The Future of Economics: An Islamic Perspectiv. Jakarta: Sharia Economic and Banking Institute, 2001.

Departemen Pendidikan Nasional. Ensiklopedi Islam. Jakarta: PT. Ichtiar Baru Van Hoeve, 2003.

Departemen Agama RI. Al-Quran dan Terjemahnya. Semarang: Toha Putra, 1995.

Hamid, Nur. Jejak Langkah Sejarah Pemikiran Ekonomi Islam. Yogyakarta: Pustaka Pelajar, 2010.

Karim, Adiwarman Azwar. Sejarah Pemikiran Ekonomi Islam. Jakarta: PT. Raja Grafindo Persada, 2014.

Krugman, Paul R. dan Maurice Obsteld. International Economics; Theory and Policy. New York: Harper Collins Publisher Inc, 1991.

P3EI UII dan BI. Ekonomi Islam. Yogyakarta: PT. Raja Grafindo Persada, 2008.

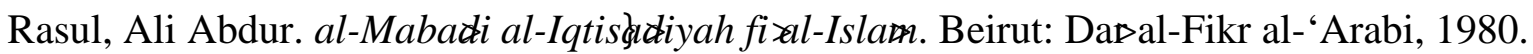

Sabiq, Sayyid. Fiqh al-Sunnah. Libanon: Daßal-Fikr, 1981.

Sukirno, Sudono. Mikro Ekonomi, Teori Pengantar. Jakarta: Raja Grafindo Persada, 2006.

Yusuf, SM. Economic Justice in Islam. New Delhi: Kitab Bavan, 1988.

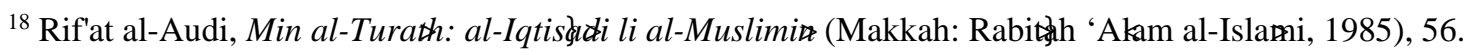

